\title{
Uterine Corpus Leiomyosarcoma and Endometrial Stromal Sarcoma pT1b TNM Finding v8
}

National Cancer Institute

\section{Source}

National Cancer Institute. Uterine Corpus Leiomyosarcoma and Endometrial Stromal

Sarcoma pT 1b TNM Finding v8. NCI Thesaurus. Code C139829.

Uterine corpus leiomyosarcoma or endometrial stromal sarcoma with tumor limited to the uterus, measuring more than $5 \mathrm{~cm}$ in greatest dimension. (from AJCC 8th Ed.) 